\title{
The Immunity of the United Nations in Relation to the Genocide in Srebrenica in the Eyes of a Dutch District Court
}

\author{
Otto Spijkers* \\ Grotius Centre for International Legal Studies, Faculty of Law, \\ Leiden University, Steenschuur 25, 2311 ES Leiden, the Netherlands \\ o.spijkers@law.leidenuniv.nl
}

\begin{abstract}
The Srebrenica genocide has come before three different courts in The Hague, the Netherlands. The International Court of Justice looked at the responsibility of the Republic of Serbia; the International Criminal Tribunal for the former Yugoslavia looked at the responsibility of certain individuals. No court has as yet dealt with the responsibility of the United Nations ('UN') itself. Ten relatives of victims of the genocide and a foundation called the Mothers of Srebrenica believed this to be a role for the judges of the District Court in The Hague. However, on 10 July 2008, the Dutch Court affirmed the UN's immunity and declared it had no jurisdiction to hear the action against it. This article discusses that judgment. It will look at the applicable immunity provisions, i.e. Article 105 of the UN Charter and the Convention on the Privileges and Immunities of the United Nations, their conceptual foundation (the doctrine of functional necessity), and the role of the Dutch Court in interpreting and applying these provisions. It will also look at a possible clash between respect for the absolute immunity of the UN and other legal obligations for the Netherlands, including those under the Genocide Convention, and the European Convention on Human Rights.
\end{abstract}

\section{Keywords}

peacekeeping; peace operations; immunity; functional necessity; United Nations; Srebrenica; attribution; genocide; right to a fair trial

*) $\mathrm{PhD}$ Candidate at Leiden University. This article is an expanded version of a post published on the blog The Invisible College (www.invisiblecollegeblog.com). I wish to thank Eric De Brabandere, Eun Seong Hwang and Boris Kondoch for comments on earlier drafts. 


\section{Introduction}

The Srebrenica genocide has come before a number of different courts in the city of The Hague, the Netherlands. ${ }^{1}$ In 2007, the International Court of Justice (ICJ) found Serbia guilty of a failure to prevent the genocide in Srebrenica, and a failure to punish the main perpetrators. ${ }^{2}$ On 25 May 1993, the United Nations Security Council established the International Criminal Tribunal for the former Yugoslavia (ICTY), which has since then tried a number of individuals held responsible for war crimes, genocide, and crimes against humanity, including those committed in Srebrenica. ${ }^{3}$ No court has as yet dealt with the responsibility of the United Nations. Ten relatives of victims of the genocide and a foundation called the Mothers of Srebrenica believed this to be a role for the judges of the District Court in The Hague. ${ }^{4}$ The Mothers of Srebrenica argue that both the United Nations and the Netherlands failed to prevent the genocide in Srebrenica in the mid-nineties. By doing so, both have committed a wrongful act. ${ }^{5}$ The United Nations did not respond to

1) See also The Hague Justice Portal's Report, Srebrenica in Summary: An Overview of the Legal Proceedings Relating to the 1995 Genocide, published 7 August 2008 (http://www .haguejusticeportal.net).

2) Judgment in the Case Concerning the Application of the Convention on the Prevention and Punishment of the Crime of Genocide (Bosnia and Herzegovina v. Serbia and Montenegro) ('Genocide Case'), 26 February 2007. This was after Montenegro had declared its independence and was removed from the case.

3) Security Council Resolution 827, 25 May 1993. Mr. Radovan Karadžić, one of the two alleged masterminds of the genocide in Srebrenica, was recently surrendered to the ICTY, located in The Hague. Karadzic already indicated that his main intention is to tell the truth about Srebrenica, i.e. to deny that genocide was committed and to highlight the role of the international community, including the Netherlands, there. See 'Karadzic's Defense Strategy: No Genocide in Srebrenica', an article published in Blic (Serbian daily newspaper) of 7 August 2008.

4) In 2003, the same Dutch District Court was asked, by a different foundation also representing the victims of the genocide, to allow the hearing of certain witnesses, who could give evidence to support the claim that the Netherlands had a sufficient degree of control to be co-responsible with the UN. Then, the District Court refused to call these witnesses, because it was as yet unclear whether it was possible, under international law, that together with the UN the Netherlands could be held responsible. See The Hague District Court, Association Udruzenja Gradana "Zene Srebrenice" Tuzla v. the Netherlands, judgment of 27 November 2003, Case no. 03.531, referred to in Zwanenburg, Accountability under International Humanitarian Law for United Nations and North Atlantic Treaty Organization Peace Support Operations (Leiden: E.M. Meijers Instituut, 2004), p. 285.

5) Plaintiffs also argued that the UN failed to comply with an agreement (or 'contract') to protect the civilians of Srebrenica. Writ of Summons, para. 288. All documents of the plaintiffs 
these allegations, and chose instead to rely on its immunity. On 10 July 2008, the District Court in The Hague affirmed the UN's immunity and declared it thus had no jurisdiction to hear the action against the United Nations. ${ }^{6}$ This article aims to discuss the latter judgment. ${ }^{7}$

\section{The Facts}

Before analyzing the Dutch Court's decision, a brief summary of the relevant facts will be provided. ${ }^{8}$ According to the ICJ, 'the atrocities committed in and around Srebrenica are nowhere better summarized than in the first paragraph of the Judgment of the Trial Chamber in the Krstic case'?

Despite a UN Security Council resolution declaring that the enclave was to be "free from armed attack or any other hostile act", units of the Bosnian Serb Army ("VRS") launched an attack and captured the town. Within a few days, approximately 25,000 Bosnian Muslims, most of them women, children and elderly people who were living in the area, were uprooted and, in an atmosphere of terror, loaded onto overcrowded buses by the Bosnian Serb forces and transported across the confrontation lines into Bosnian Muslimheld territory. The military-aged Bosnian Muslim men of Srebrenica, however, were consigned to a separate fate. As thousands of them attempted to flee the area, they were taken prisoner, detained in brutal conditions and then executed. More than 7,000 people were never seen again. ${ }^{10}$

(press releases, writ of summons, etc.) are available on the website of the law firm: http://www .vandiepen.com. An English translation is also provided there.

6) Judgment in the Incidental Proceedings, in the case between the Foundation Mothers of Srebrenica et al. versus the Netherlands and the United Nations, District Court The Hague, case no. 295247, judgment of 10 July 2008 ('Judgment in the Incidental Proceedings'). The English translation of the Dutch judgment is available at www.rechtspraak.nl (the search engine is available at http:// zoeken.rechtspraak.nl).

7) See also den Dekker, Immunity of the United Nations before the Dutch Courts, Report of 28 July 2008, available on the Hague Justice Portal: http://www.haguejusticeportal.net/.

8) See also paras. 2.1-2.16 in M. M.-M., D.M and A.M. (Mustafic) and H.N. (Hasan Nuhanovic) versus the State of the Netherlands, District Court The Hague, case nos. 265618 and 265615, judgments of 10 September 2008 ('Mustafic' and 'Nuhanovic'). Mustafic was an electrician working for Dutchbat, who was killed during the fall of Srebrenica. Nuhanovic was an interpreter for Dutchbat; his parents and younger brother were also present in the enclave, and it is presumed that they were killed. In both cases, the surviving relatives claimed the Netherlands did not do enough to protect those presumably killed by the Bosnian-Serbs.

9) Judgment in the ICJ Genocide Case, para. 278.

10) ICTY, Prosecutor v. Krstic, Case No: IT-98-33-T, Judgment (Trial), 2 Augustus 2001, para. 1. 
What this summary fails to mention, however, is that the United Nations Protection Force (UNPROFOR) was present in Srebrenica when the genocide took place. In addition, all UNPROFOR peacekeepers stationed in Srebrenica at the time came from the Netherlands. ${ }^{11}$ This explains why the plaintiffs hold the United Nations and the Netherlands responsible for a failure to prevent the genocide. ${ }^{12}$

\section{The Principal Question}

The 'principal question' was the immunity of the United Nations from Dutch jurisdiction. ${ }^{13}$ Even if the Dutch Court did have jurisdiction according to the Dutch Code of Civil Procedure, certain norms of international law could provide an exception to those rules. ${ }^{14}$ One such exception could very well be found in the rules of international law on the immunity of the United Nations.

The Organization never directly contacted the Dutch Court, and did not appear before it to defend its immunity. ${ }^{15}$ It was the Netherlands that pleaded for the immunity of the United Nations instead. The Court agreed to hear the

11) For an overview of the facts, including the acts and omissions of the UN and the Netherlands, see Spijkers, 'Legal Mechanisms to Establish Accountability for the Genocide in Srebrenica', Human Rights \& International Legal Discourse, vol. 2, 2007, pp. 231-265.

12) A comparable situation occurred in Rwanda, where a genocide took place between April and July 1994. The United Nations Assistance Mission for Rwanda (UNAMIR) was present at that time. When two lawyers prepared to sue the United Nations in a national court for its role in the Rwandan genocide, the United Nations indicated its readiness to invoke its immunity. See Riley, 'UN to Seek Immunity on Rwanda', in Sydney Herald of 14 January 142000 . I understood from one of the lawyers involved in the case, Mr. Michael Hourigan, that the dispute never made it to court.

13) See para. 5.9, Judgment in the Incidental Proceedings.

14) See para. 5.10, Judgment in the Incidental Proceedings. The Dutch Court did not say anything about whether it has jurisdiction with regard to the dispute between the plaintiffs and the Netherlands. If the Court has such jurisdiction, then Article 7 of the Code of Civil Procedure ('Wetboek van Burgerlijke Rechtsvordering') gives the Dutch Court jurisdiction also with regard to the United Nations. However, according to Article 13a of the General Provisions Act ('Wet Algemene Bepalingen'), '[t]he jurisdiction of the Court and the enforceability of judicial decisions and of authentic deeds are restricted by exceptions recognized by international law.'

15) The United Nations only sent a letter to the Dutch Government indicating it wished to rely on its immunity. This is consistent with the UN's established practice. See e.g., para. 72, The Practice of the United Nations, May 1967, UNDoc. A/CN.4/L.118 and Add.l and 2 ('The Practice of the United Nations'); Memorandum to the Legal Adviser, UNRWA, 28 February 1984, published in UN Juridical Yearbook 1984, pp. 188-189. 
plea as the Netherlands being a member of the United Nations and a State party to the Convention on the Privileges and Immunities of the United Nations ('Immunities Convention'), had a legal interest in the granting of immunity to the Organization, and perhaps even an obligation to defend it. ${ }^{16}$ The Court thus had to decide on the UN's immunity with the help of the arguments presented to it by the Netherlands and the Mothers of Srebrenica. ${ }^{17}$

\subsection{Article 105 of the UN Charter and the Immunities Convention}

The applicable immunity provisions are Article 105 of the UN Charter and a number of articles in the Immunities Convention. ${ }^{18}$ Article 105, paragraph 1, of the UN Charter, reads as follows:

The Organization shall enjoy in the territory of each of its Members such privileges and immunities as are necessary for the fulfillment of its purposes. ${ }^{19}$

The Immunities Convention further specifies these immunities. Article II, Section 2, of this Convention reads:

The United Nations [...] shall enjoy immunity from every form of legal process except insofar as in any particular case it has expressly waived its immunity. ${ }^{20}$

16) See para. 5.6 of the Judgment in the Incidental Proceedings. The Netherlands referred to the ICJ, Difference Relating to Immunity from Legal Process of a Special Rapporteur of the Commission on Human Rights, Advisory Opinion of 29 April 1999, para. 61. See para. 3.3.5 Incidentele Conclusie of the State (on file with the author). See also, den Dekker, Immunity of the United Nations before the Dutch Courts pp. 2-3; Reinisch, International Organizations before National Courts (Cambridge: Cambridge University Press, 2000), p. 138.

17) See Writ of Summons, paras. 447-465.

18) See para. 5.11, Judgment in the Incidental Proceedings.

19) At the San Francisco Conference, where the UN Charter was drafted, Belgium, Mexico and Canada suggested to include a provision on immunity in the charter (see, respectively, Documents of the United Nations Conference on International Organization ('UNCIO'), vol. 3, pp. 343-344, p. 96, and p. 595).

20) The drafting history of this Convention is almost as old as that of the UN Charter itself. It begins with a Report by the Executive Committee to the Preparatory Commission of the United Nations, 12 November 1945, UN Doc. PC/EX/113/Rev.1 (on this Commission, see Yearbook of the United Nations 1946-47, pp. 34-35). Based on this report, the Preparatory Commission of the United Nations then drafted a Convention on Privileges and Immunities (see UNDoc. PC/20, 23 December 1945, pp. 60-80). Based on this draft followed a 'particularly exhaustive and thorough' discussion at the Sixth Committee of the General Assembly (see Report of the Sixth Committee, UNDoc. A/43/Rev, p. 642, and the First and Second Report of the Sub-Committee 
When looking at the drafting history of these two provisions, it becomes clear that the immunities of the UN were not based on ideas similar to those which formed the basis of state immunity. ${ }^{21}$ Instead, the UN's immunities were as extensive as was considered necessary for the Organization to function, and as restrictive as was required to ensure respect for the sovereignty of its Member States. ${ }^{22}$ When it came to immunity from domestic jurisdiction, this balancing led to immunity from every form of legal process.

\subsection{The Immunity of the UN Based on Functional Necessity}

The question remains whether the United Nations can rely on these immunity provisions in the present case. In an attempt to answer this question, the Dutch Court first noted that the plaintiffs' complaints related to 'acts (and omissions) in the implementation of [a] peace-keeping mission'. ${ }^{23}$ Such acts 'fall within the functional scope of the [United Nations]'. ${ }^{24}$ In view of

on Privileges and Immunities (UNDoc A/C.6/17 and A/C.6/31)). The Convention's text was offered to the members of the General Assembly in the form of a Convention. The resolution was adopted by consensus (UNDoc A/PV.31, p. 455; General Assembly Resolution 22 (I), adopted 13 February 1946, UNDoc. A/RES/22(I)). The Immunities Convention entered into force in September 1946 (see United Nations, Treaty Series, vol. 1, p. 15). The Netherlands is a party to this treaty since April 1948.

21) Where it came to the immunities of the Organization itself, the relevant Subcommittee at San Francisco believed that in order to determine the nature of the privileges and immunities it would be better to avoid the term 'diplomatic,' a term Mexico referred to in its proposals, and instead refer to 'a more appropriate standard, based, for the purposes of the Organization, on the necessity of realizing its purposes' (UNCIO, vol. 13, pp. 779).

22) The Executive Committee to the Preparatory Commission noted that the UN's immunities would need to be quite extensive, but that ' $[\mathrm{i}] \mathrm{t}$ should be a principle that no immunities and privileges, which are not really necessary, should be asked for' (Report by the Executive Committee, p. 70, para. 5). Sir Hartley Shawcross (UK) remarked, at the time the Convention was adopted by the General Assembly, that 'in setting up this great new international Organization we should not ask for it to possess privileges and immunities which are greater than those required for its efficient organization [because] [ $\mathrm{t}$ ] hat would lead to unnecessary conflicts with the national sovereignty of particular Member States' (p. 452, UNDoc A/PV.31.) However, '[t]o give too few [immunities] would fetter the United Nations Organization in the discharge of its tasks' (idem). A balance thus needed to be sought. In Shawcross' view, the Convention had achieved that balance: '[w]ithin the scope and the ambit of the [UN] Charter this Convention will give the United Nations Organization, in every Member State, a sufficient degree of sovereignty in regard to its own affairs to enable it to carry out its functions independently, impartially and efficiently' (idem).

23) See para. 5.12, Judgment in the Incidental Proceedings.

24) Idem. 
the Court this is important because '[i]t is particularly for acts within this framework that immunity from legal process is intended'. ${ }^{25}$

The fact that this question as to whether the acts or omissions complained of fell within the functional scope of the Organization was raised at all gives the impression that the immunity of the United Nations only covers acts that fall within that functional scope. This limitation of immunity of the UN is only meaningful if the Organization can also commit acts that are 'nonfunctional', i.e. that do not fall within the Organization's functional scope. ${ }^{26}$ If non-functional acts exist at all, then one would think that the failure to prevent genocide would certainly fit in that category.

However, the scope of immunity of international organizations is not generally viewed as such. There is almost universal agreement that the immunity of international organizations is based on the doctrine of functional necessity, the central idea of which is that 'international organizations should possess the minimum immunities necessary to perform their functions'. ${ }^{27}$ To apply this doctrine, one need not look at the particular acts objected to in order to determine whether they were necessary to fulfill the purposes of the Organization. It is clear that a failure to prevent genocide is not necessary to accomplish the purposes of the UN. Instead, one must assess the negative consequences the denial of immunity would have for the proper functioning of the UN. ${ }^{28}$

25) Idem. The use of two different words 'scope' and 'framework' is confusing. In the Dutch version of the Judgment, the same word is used, and thus the word 'framework' in the last sentence, refers to 'scope' in the previous sentence.

26) See Reinisch, International Organizations before National Courts, pp. 342-346.

27) Brower, 'International Immunities', p. 5 (see also p. 18). Emphasis in the original. See also Gerster, Rotenberg, 'Article 105', in Simma (ed.), The Charter of the United Nations: A Commentary, 2nd edition (Oxford: Oxford University Press, 2002), p. 1317; Amerasinghe, Principles of the Institutional Law of International Organizations, 2nd Edition (Cambridge: Cambridge University Press, 2005), p. 316; Reinisch \& Weber, 'In the Shadow of Waite and Kennedy: the Jurisdictional Immunity of International Organizations, the Individual's Right of Access to the Courts and Administrative Tribunals as Alternative Means of Dispute Settlement', in International Organizations Law Review, vol. 1, 2004, no. 1, p. 59; Reinisch, International Organizations Before National Courts, p. 205; Kunz, 'Privileges and Immunities of International Organizations', the American Journal of International Law, vol. 41, 1947, no. 4, p. 847; Rawski, 'To Waive or Not to Waive: Immunity and Accountability in U.N. Peacekeeping Operations', in Connecticut Journal of International Law, vol. 18, 2002, no. 1, pp. 106-107; Klein, La responsabilité des organisations internationales dans les ordres juridiques internes et en droit des gens (Brussels: Bruylant, 1998), p. 230; etc.

28) See Reinisch, International Organizations before National Courts, p. 365; Klabbers, An Introduction to International Institutional Law (Cambridge: Cambridge University Press, 2002), pp. 150-151. 
The question is thus whether it is necessary for the United Nations, in order to fulfill its purposes, to have immunity from domestic jurisdiction in cases relating to acts committed (or 'omitted') by a UN peacekeeping force. When answering this question, one must consider that no organization has the right to claim 'a quiet life, and certainly not a charmed life, set apart from the bustle and travails of the world'. ${ }^{29}$ In other words, there must be convincing reasons for granting immunity from domestic jurisdiction to the United Nations. $^{30}$

\subsection{A Duty to Waive}

Before addressing the plaintiffs' arguments relating to the scope of the UN's immunities, the Dutch Court first looked at the possibility of the United Nations to waive its immunity in certain circumstances. ${ }^{31}$ With regard to officials and experts, the Immunities Convention states:

The Secretary-General shall have the right and the duty to waive the immunity of any official [or expert] in any case where, in his opinion, the immunity would impede the course of justice and it can be waived without prejudice to the interests of the United Nations. ${ }^{32}$

29) Singer, 'Jurisdictional Immunity of International Organizations', p. 128.

30) The International Law Commission's Special Rapporteur on Relations between States and International Organizations gave the following reasons for the immunity of international organizations: 'to guarantee the autonomy, independence and functional effectiveness of international organizations and protect them against abuse of any kind, and because national courts are not always the most appropriate forum for dealing with lawsuits to which international organizations may be parties.' para. 24 of Diaz-Gonzalez, Fourth Report on Relations between States and International Organizations, UNDoc. A/CN.4/424, 24 April 1989 (see also paras. 27 and 56). See also Arsanjani, 'Claims against International Organizations', in Yale Studies in World Public Order, vol. 7, 1981, p. 163; Pingel, 'Article 105', p. 2159; Bowett, Sands \& Klein, Bowett's Law of International Institutions, 5th Edition (London: Sweet \& Maxwell, 2001), p. 491; Amerasinghe, Principles of the Institutional Law of International Organizations, p. 317; Singer, 'Jurisdictional Immunity of International Organizations', p. 85; Dominicé, 'Limmunité de juridiction et d'exécution des organisations internationales', in Recueil des cours, vol. 187, 1984, p. 161.

31) See Judgment in the Incidental Proceedings, para. 5.13. See also Brower, 'International Immunities', pp. 27-30.

32) Article V, Section 20 (on officials) and 23 (identical provision on experts) of the Immunities Convention. In practice, the UN has often waived immunity in cases relating to car accidents in which UN personnel was involved. See The Practice of the United Nations, para. 84. See also Supplementary Study to The Practice of the United Nations, July 1985, UNDoc. A/CN.4/L.383 and Add.1-3, pp. 158-159. 
When it comes to the immunity of the Organization itself, there is no such provision. ${ }^{33}$ The existence of an implied right to waive immunity of the UN is uncontroversial. ${ }^{34}$ The question remains, however, as to whether there is a duty to do so in certain circumstances. It is generally believed that there is no such duty, and if there were one, it would not be up to the Dutch Court to decide whether the Organization respected this duty. ${ }^{35}$ The Court seems to have reached the same conclusion. ${ }^{36}$ After all, the Dutch Court did not mention such a duty at all. Instead, it looked only at whether the UN had actually waived its immunity in the present case, and the conclusion reached by the Court was that it had clearly not done so.

\subsection{Role of the Dutch Court in Applying the Functional Necessity Doctrine}

The plaintiffs argued that the failure to prevent genocide did not accord with the purposes of the UN. This omission, therefore, did not fall within its functional scope, and the Organization was thus not entitled to immunity for this omission. ${ }^{37}$ However, the Dutch Court duly chose not to look at the necessity of the UN's failure to prevent genocide for the fulfillment of the Organization's purposes. As explained above, such an assessment would have been based on a mistaken interpretation of the functional necessity doctrine. ${ }^{38}$

Instead, the Dutch Court decided not to apply the functional necessity doctrine at all. It reasoned that Article 105 of the UN Charter prescribed the application of the necessity doctrine to the immunities of the United Nations. Since the Immunities Convention was based on that Article, the drafters of

33) See e.g., Amerasinghe, Principles of the Institutional Law of International Organizations, p. 350; Wellens, Remedies against International Organizations (Cambridge: Cambridge University Press, 2002), p. 212.

34) See Franck \& Chesterman, Law and Practice of the United Nations: Documents and Commentary (New York: Oxford University Press, 2008), p. 513.

35) Article VIII, Section 30, of the Immunities Convention suggests that this would be a job for the International Court of Justice.

36) This might lead one to believe that there is more chance to sue some major UN officials instead of the Organization itself. However, the UN generally accepts the acts of such officials as its own. See Review of the Efficiency of the Administrative and Financial Functioning of the United Nations, UNDoc. A/C.5/49/65, 24 April 1995, para. 30; and para. 50 of Hampson, Administration of Justice, Rule of Law and Democracy, 7 July 2005, UNDoc. E/CN.4/ Sub.2/2005/42.

37) See Writ of Summons, para. 450.

38) See section 3.2 of this article, above. 
the Immunities Convention had already applied the functional necessity doctrine to the immunity of the United Nations, thus concluding that the UN needed absolute immunity from national legal process to fulfill its purposes. ${ }^{39}$

Almost all scholars accept this as a reasonable outcome. ${ }^{40}$ The main arguments in support of this conclusion are that national courts could be biased against the Organization, and various national courts would probably apply the doctrine of functional necessity in various ways, with various outcomes. ${ }^{41}$ Thus, though it may be true that international organizations are generally inclined to interpret their own immunities as broadly as possible, the Dutch Court's decision was warranted in leaving the determination of the necessary immunities to the international organization itself. ${ }^{42}$

\subsection{Significance of the Lack of an Alternative Dispute Settlement Mechanism}

When the Dutch Courts are unable to deal with claims for reparation of damages caused by certain acts and omissions of the United Nations, the next logical step is to determine who is. From an Advisory Opinion of the International Court of Justice, the Dutch Court derived a general rule that

39) See Judgment in the Incidental Proceedings, para. 5.14. See also den Dekker, Immunity of the United Nations before the Dutch Courts, p. 4; Singer, 'Jurisdictional Immunity of International Organizations', p. 84. And see Memorandum to the Legal Adviser, pp. 188-189. In 1985, the UN proudly stated that despite the fact that the immunity of States continued to erode, and despite the fact that other international organizations saw their immunity restricted, ' $[t]$ he United Nations [...] has continued to enjoy unrestricted immunity from legal process and has experienced no particular difficulties in this regard.' The Practice of the United Nations (Supplement), Para. 11 (p. 161).

40) See Singer, 'Jurisdictional Immunity of International Organizations', p. 57; Gerster, Rotenberg, 'Article 105', p. 1318; Arsanjani, 'Claims against International Organizations', p. 163; The Practice of the United Nations, para. 76 (p. 224); Brower, 'International Immunities', pp. 26-27; Pingel, 'Article 105', p. 2160; Bowett, Sands \& Klein, Bowett's Law of International Institutions, p. 490; Franck \& Chesterman, Law and Practice of the United Nations, p. 513; Reinisch \& Weber, 'In the Shadow of Waite and Kennedy', p. 63; Reinisch, International Organizations Before National Courts, pp. 332-336; Wellens, Remedies against International Organizations, p. 121: speaks of 'absolute "functional” immunity', see also den Dekker, Immunity of the United Nations before the Dutch Courts, p. 4.

41) See Reinisch, International Organizations Before National Courts, p. 206. See also Klabbers, An Introduction to International Institutional Law, p. 167; Singer, 'Jurisdictional Immunity of International Organizations', pp. 108-109.

42) In case of the United Nations, it helps that most UN member states have explicitly accepted the outcome of the application of this doctrine to and by the Organization by becoming a party to the Immunities Convention. 
'wrongful acts possibly committed by the UN are not open to assessment by national courts, but should take place in the context of specific dispute settlement as provided for in article VIII, paragraph 29 of the [Immunities Convention]'. ${ }^{43}$ According to this Article:

The United Nations shall make provisions for appropriate modes of settlement of [...] disputes arising out of contracts or other disputes of a private law character to which the United Nations is a party. ${ }^{44}$

\section{The United Nations has consistently interpreted this to mean that if immunity} is not waived, some alternative method to settle the dispute should be found. ${ }^{45}$ This rule was also applied, by the UN itself, to its peacekeeping missions. In 1990, the United Nations advocated the establishment of a standing claims commission for peacekeeping forces. ${ }^{46}$ More specifically, in an agreement

43) See Judgment in the Incidental Proceedings, para. 5.15. The opinion referred to was ICJ, Difference Relating to Immunity from Legal Process of a Special Rapporteur of the Commission on Human Rights, Advisory Opinion of 29 April 1999, para. 66.

44) The Executive Committee, responsible for the first draft of the Immunities Convention, noted that 'where the United Nations [...] concludes contracts with private individuals or corporations, it should include in the contract an undertaking to submit to arbitration disputes arising out of the contract, if it is not prepared to go before the [local] Courts' (Report by the Executive Committee, p. 70, para. 5).

45) Although it is true that the UN has as its main purpose to maintain international peace and security, another one of the Organization's purposes is 'promoting and encouraging respect for human rights and for fundamental freedoms', including the right to a fair trial. See Article 1(3), UN Charter. It would be strange if the UN would promote these purposes, but not apply them to its own actions. See also Effect of Awards of Compensation made by United Nations Administrative Tribunal, Advisory Opinion of July 13th, 1954, p. 57; cited in Reinisch \& Weber, 'In the Shadow of Waite and Kennedy', p. 70. See also para. 386 (p. 296), The Practice of the United Nations; para. 52, The Legal Counsel of the United Nations, Written Statement Submitted on Behalf of the Secretary-General of the United Nations, 2 October 1998, and paras. 13-15, Legal Counsel, Written Comments Submitted on Behalf of the Secretary-General of the United Nations, 30 October 1998, both in the case ICJ, Difference relating to Immunity from Legal Process of a Special Rapporteur of the Commission on Human Rights (documents available at http://www.icj-cij.org). See Brower, 'International Immunities', pp. 71-72; Wellens, Remedies against International Organizations, pp. 210-211. And Reinisch, 'Securing the Accountability of International Organizations', Global Governance, vol. 7, 2001, pp. 131-149.

46) See para. 51, Comprehensive Review of the Whole Question of Peace-Keeping Operations in All Their Aspects, 9 October 1990, UNDoc. A/45/594; Review of the Efficiency of the Administrative and Financial Functioning of the United Nations, paras. 15-20. See also Arsanjani, 'Claims against International Organizations', pp. 141-143, where we see that such agreements where concluded also for some of the earliest peacekeeping missions; Dominicé, 'Limmunité de juridiction 
between the UN and Bosnia and Herzegovina, it is stated that 'any dispute or claim of a private law character to which UNPROFOR or any member thereof is a party and over which the courts of Bosnia and Herzegovina do not have jurisdiction [...] shall be settled by a standing claims commission to be established for that purpose'. ${ }^{47}$ However, it seems such a standing claims commission was never established. ${ }^{48}$ Moreover, the UN did not create any alternative dispute settlement mechanism in relation to Srebrenica.

There is no disagreement over the desirability of having some kind of international or UN-dispute settlement mechanism to substitute the dispute settlement mechanism provided by national courts, if immunity is granted there and the Organization does not waive it. ${ }^{49}$ Clearly, the lack of such a $\mathrm{UN}$-mechanism in the present case is unfortunate, but the question is whether it should also have legal consequences relating to immunity. ${ }^{50}$ According to the Dutch Advisory Commission on Problems of Public International Law, if there are no 'adequate legal remedies available to the aggrieved party within

et d'exécution des organisations internationales,' p. 202; Klein, La responsabilité des organisations internationales, pp. 262-267.

47) Article 48 of the 'Agreement on the Status of the United Nations Protection Force in Bosnia and Herzegovina', in United Nations Treaty Series, vol. 1722 (1993), p. 86. The State referred to these provisions (see para. 3.4.10 Incidentele Conclusie, and 2.23 of the State's Memorandum of Oral Pleading). See also para. 2.5 of both Mustafic and Nuhanovic.

48) Plaintiffs argued that such a commission was never established (para. 57, plaintiffs' Memorandum of Oral Pleading). More generally, see e.g. footnote 49 of Hampson, Administration of Justice, Rule of Law and Democracy; Arsanjani, 'Claims against International Organizations,' p. 163; Wellens, Remedies against International Organizations, pp. 98, 103. A local claims review board composed exclusively of UN staff is often established, but that is generally considered unsatisfactory. See e.g., International Law Association, 'Berlin Conference (2004)', p. 216.

49) See Blokker \& Schermers, International Institutional Law: Unity within Diversity, 4th revised edition (Leiden: Nijhoff, 2003), pp. 1026-1027; Wellens, Remedies against International Organizations, p. 114; Article 8, Institut de Droit International, Conditions of Application of Humanitarian Rules of Armed Conflict to Hostilities in which United Nations Forces May be Engaged, resolution adopted at the Session of Zagreb, 1971; International Law Association, 'Berlin Conference (2004): Accountability of International Organizations', in International Law Association Reports of Conferences, vol. 71, 2004, pp. 219-220 and 228; Section 3.5.2, Commissie van Advies inzake Volkenrechtelijke Vraagstukken, Advies inzake Aansprakelijkheid voor Onrechtmatige Daden tijdens UN Vredesoperaties, Report of 8 May 2002; Gaillard \& PingelLenuzza, 'International Organisations and Immunity from Jurisdiction: to Restrict or to Bypass', The International and Comparative Law Quarterly, vol. 51, 2002, no. 1, p. 10.

50) See also Yassin Abdullah Kadi v. Council of the European Union and Commission of the European Communities, Judgment of the European Court of Justice (Grand Chamber) of 3 September 2008, Case no. C-402/05 P ('Kadi (ECJ)'), paras. 318-328. 
the international organization itself [..] it is desirable that national courts do not grant immunity and proceed to the settlement of the dispute. ${ }^{51}$ However, the Dutch Advisory Commission also made clear that, in its opinion, this was a description of the desired development of the law, not a statement of already existing law. Therefore, despite the fact that it is generally agreed that the shield of immunity must be accompanied by the sword of justice, ${ }^{52}$ it could be argued that the Dutch Court was probably justified in saying that, according to existing law, this lack of any dispute mechanism did not by itself prevent the United Nations from invoking its absolute immunity. ${ }^{53}$

The general conclusion of the Dutch Court is thus that 'the interpretation of article 105 of the UN Charter [and the Immunities Convention] does not offer grounds for restricting the immunity'. ${ }^{54}$

\subsection{A Clash between Respect for Absolute Immunity and Other Obligations}

The possibility that certain norms are so important that they overrule, or 'trump' the immunity of all domestic legal processes provided to the UN is still left open. Indeed, in view of the Dutch Court, the 'priority rule' of Article 103 of the UN Charter ${ }^{55}$ cannot be interpreted to mean that obligations under the Charter such as the duty to respect the immunity of the UN, always and automatically overrule other obligations a State may have, especially if those other obligations have a jus cogens nature. ${ }^{56}$

51) Section 4.5.2, Advies inzake aansprakelijkheid voor onrechtmatige daden tijdens UN vredesoperaties. The translation is my own.

52) Dominicé, 'L'immunité de juridiction et d'exécution des organisations internationales', p. 226: '[l]e bouclier défensif que constituent nos immunités doit être accompagné du glaive de la justice'. Klein called the obligation for the organization to provide a legal remedy the 'contrepartie naturelle' of immunity, see Klein, La responsabilité des organisations internationales, p. 247.

53) See para. 5.15, Judgment in the Incidental Proceedings. This argument was also used - and rejected - in Manderlier v. the United Nations and Belgian State. See United Nations Juridical Yearbooks of 1966, p. 283; and 1969, pp. 236-237. See also Dominicé, 'L'immunité de juridiction et d'exécution des organisations internationales', p. 182.

54) See para. 5.15, Judgment in the Incidental Proceedings.

55) See para. 5.16, Judgment in the Incidental Proceedings. Article 103 UN Charter says that '[i]n the event of a conflict between the obligations of the Members of the United Nations under the [UN] Charter and their obligations under any other international agreement, their obligations under the present Charter shall prevail.'

56) See para. 5.16, Judgment in the Incidental Proceedings. For a definition of jus cogens, see Article 53, Vienna Convention on the Law of Treaties. This view is different from the view held by the same Court in relation to the claims made by Slobodan Milošević, a few years ago. See para. 5.1, 
With regard to 'trumping,' two different arguments were made. First, the plaintiffs argued that, since the Netherlands had a legal obligation under the Genocide Convention to prevent and punish genocide, ${ }^{57}$ it also had a legal obligation to provide a civil remedy to the Mothers of Srebrenica in respect of the failure to prevent genocide allegedly 'committed' by the United Nations. ${ }^{58}$ In other words, as party to the Genocide Convention, the Netherlands must not obstruct any efforts of the international community to win the battle against genocide. Second, they argued that the Netherlands had a legal obligation to secure for everyone within its jurisdiction the unhindered enjoyment of human rights, including the right to a fair trial. ${ }^{59}$ If the Dutch Court would accept the immunity of the United Nations, it would make it impossible for the plaintiffs to enjoy this human right. In making this argument, the plaintiffs relied on the fair trial articles of the European Convention on Human Rights and the International Covenant on Civil and Political Rights. ${ }^{60}$ Article 10

The Hague District Court, Milosevic v. International Criminal Tribunal for the Former Yugoslavia and the Netherlands, Judgment of 26 February 2002, Case no. KG 02/105, and para. 3.5, The Hague District Court, Milosevic v. The Netherlands, Judgment of 31 August 2001, Case no. KG 01/975.

57) According to Article I of the Convention on the Prevention and Punishment of the Crime of Genocide, '[ $t$ ] he Contracting Parties confirm that genocide, whether committed in time of peace or in time of war, is a crime under international law which they undertake to prevent and to punish.' Entry into force 12 January 1951 (for the Netherlands 20 June 1966), United Nations, Treaty Series, vol. 78, p. 277.

58) The prohibition to commit genocide is certainly a jus cogens norm. The plaintiffs did refer to the jus cogens nature of the prohibition to commit genocide, which has been acknowledged by the ICJ. See Statement of Defence in the Interim Proceedings, 6 February 2008, paras. 40-47. The case referred to was ICJ, Case Concerning Armed Activities on the Territory of the Congo (New Application: 2002) (Democratic Republic of the Congo v. Rwanda), Jurisdiction of the Court and Admissibility of the Application, 3 February 2006, Para. 64.

59) It is not so clear whether the right to a (fair) trial is jus cogens. See Yassin Abdullah Kadi v Council of the European Union and Commission of the European Communities, Judgment of the ECJ (Court of First Instance) of 21 September 2005, case no. T-315/01, ('Kadi (CFI)'). The Court of First Instance did consider the right to a trial to be of jus cogens character (paras. 277292), but it also considered that the limitations caused by the UN's immunity were 'inherent in that right as it is guaranteed by jus cogens' (para. 288). The judgment has been successfully appealed: see Kadi (ECJ).

60) Article 14 of the International Covenant on Civil and Political Rights (Entry into force 23 March 1976 (for the Netherlands 11 December 1978 ), United Nations, Treaty Series, vol. 999, p. 171), which states that ' $[\mathrm{i}] \mathrm{n}$ the determination of [...] his rights and obligations in a suit at law, everyone shall be entitled to a fair and public hearing by a competent, independent and impartial tribunal established by law', and Article 6 of the European Convention on 
of the Universal Declaration of Human Rights also guarantees a fair trial and a right to court, ${ }^{61}$ but the plaintiffs decided not to rely on that provision, probably because General Assembly resolutions are legally non-binding. ${ }^{62}$

\subsection{The Overriding Obligations under the Genocide Convention}

The plaintiffs were not successful with their first argument. The Dutch Court did not believe, as the plaintiffs suggested, that the Genocide Convention's obligations to prevent and punish included the duty to help provide compensation by means of providing a civil suit for an alleged past failure to prevent genocide. ${ }^{63}$ In the case of Al-Adsani v. The United Kingdom, Al-Adsani made a similar argument. A victim of torture, he argued that the UK's obligation to secure respect for the prohibition of torture, which also has a jus cogens character, included a duty to assist him in seeking compensation by means of a civil suit in a British court. ${ }^{64} \mathrm{He}$ was also unsuccessful. ${ }^{65}$

Provided the Genocide Convention gave birth to a duty for States to provide a civil suit for claims relating to genocide - the Dutch Court believed this

Human Rights (entry into force in September 1953 (also for the Netherlands)), which states that ' $[\mathrm{i}] \mathrm{n}$ the determination of his civil rights [...] everyone is entitled to a fair and public hearing within a reasonable time by an independent and impartial tribunal established by law.'

61) The Articles do not explicitly prescribe a human right to a trial, but it is generally agreed, both in scholarship and case law, that a right to a fair trial includes a right to a trial. See e.g., Reinisch \& Weber, 'In the Shadow of Waite and Kennedy', pp. 65-66.

62) The Universal Declaration of Human Rights (UDHR) was adopted by General Assembly Resolution 217 A (III) of 10 December 1948. In Manderlier v. the United Nations and Belgan State, the Court rejected the reliance on the UDHR because of its non-binding character. See United Nations Juridical Yearbooks of 1966, p. 283; and 1969, pp. 236-237; Reinisch, International Organizations Before National Courts, pp. 279-280. In Singer's view, however, the Universal Declaration is more binding, so to speak, than the other covenants just mentioned, because it is an interpretation of the human rights obligations arising under the Charter. Singer, 'Jurisdictional Immunity of International Organizations,' footnote 151 (p. 87, see also p. 97).

63) See paras. 5.18-5.19, Judgment in the Incidental Proceedings.

64) Idem, para. 5.20. See also para. 35, European Court of Human Rights, Case of Al-Adsani v. The United Kingdom (Application no. 35763/97), Judgment, 21 November 2001 ('Al-Adsani'). Al-Adsani contended that the UK had failed to secure his right not to be tortured, contrary to Article 3 of the Convention read in conjunction with Articles 1 and 13 (right to an effective remedy).

65) The argument was not accepted, because the torture was committed outside the jurisdiction of the forum State and there was no causal connection between the acts of torture and the forum State. Al-Adsani, paras. 40-41. 
was not the case - then this obligation would still clash with the obligation to respect the UN's immunity. ${ }^{66}$ The fact that the prohibition to commit genocide is jus cogens did not mean that any obligation arising under the Genocide Convention would automatically overrule all non-peremptory norms of international law, including the rules on immunity. This is where the Dutch Court did refer to Al-Adsani. ${ }^{67}$ On the effects of the jus cogens nature of the prohibition of torture allegedly violated by the State claiming immunity in the British torts case, the European Court concluded that,

Notwithstanding the special character of the prohibition of torture in international law, the Court is unable to discern in the international instruments, judicial authorities or other materials before it any firm basis for concluding that, as a matter of international law, a State no longer enjoys immunity from civil suit in the courts of another State where acts of torture are alleged. ${ }^{68}$

This line of reasoning, i.e. to see the issue as a clash between immunity and a jus cogens norm, is misleading. Instead of presenting it as a clash between UNor State-immunity versus the prohibition of genocide or torture, ${ }^{69}$ it is more appropriate to look at the case as essentially a clash between respect for the immunity of the United Nations, and respect for the right to a fair trial of the plaintiffs.

\subsection{Right to a Fair Trial}

Although the Dutch Court did not do so, we may begin our discussion of this clash by referring, once again, to Al-Adsani. Al-Adsani argued that the UK failed to secure his right to a fair trial by granting immunity to Kuwait. ${ }^{70}$ In assessing the fair trial argument, the European Court remarked first of all that:

66) Because the Genocide Convention does not contain such obligations, 'the [Dutch] Court does not get to a prioritizing of conflicting international-law standards.' See para. 5.21, Judgment in the Incidental Proceedings.

67) Idem, para. 5.20.

68) Al-Adsani, para. 61. A dissenting minority in Al-Adsani believed that the jus cogens nature of the prohibition of torture should have a trumping effect. See para. 4, dissenting opinion of Judge Rozakis et al. in Al-Adsani.

69) See also, de Oliveira Moll, 'Al-Adsani v United Kingdom: State Immunity and Denial of Justice with Respect to Violations of Fundamental Human Rights', in Melbourne Journal of International Law, vol. 4, no. 2, 2003, p. 588.

70) Al-Adsani, para. 42. 
A limitation [of the right to a (fair) trial] will not be compatible with Article $6 \$ 1$ [of the European Convention of Human Rights] if it does not pursue a legitimate aim and if there is no reasonable relationship of proportionality between the means employed and the aim sought to be achieved. ${ }^{71}$

In $A l$-Adsani, the limitation on the right to a (fair) trial was based on the rules of state immunity, and the Court considered that the aim underlying these rules, i.e. the promotion of 'comity and good relations between States through the respect of another State's sovereignty' was indeed a legitimate aim. ${ }^{72}$ It also believed that granting immunity to Kuwait was not a disproportionate means to secure that aim. ${ }^{73}$ The jus cogens nature of the prohibition of torture had no decisive effect on the assessment of proportionality. ${ }^{74}$ In any case, we can conclude that the salient points in deciding the clash between the right to a fair trial and state immunity were thus: 1 ) legitimate aim, and 2) proportionality.

These two points are equally salient when it comes to a clash between the right to a fair trial and the immunity of international organizations from domestic jurisdiction. ${ }^{75}$ Waite and Kennedy, which was about the immunity of the European Space Agency from domestic jurisdiction, illustrated this. ${ }^{76}$ When concluding that the rules on immunity of international organizations have a legitimate objective, the European Court pointed out that 'the attribution of privileges and immunities to international organizations is an essential means of ensuring the proper functioning of such organizations free from

71) Al-Adsani, para. 53. The court referred to Case of Waite and Kennedy v. Germany (Application no. 26083/94), Judgment of 18 February 1999 ('Waite and Kennedy') here.

72) Idem, para. 54.

73) Idem, para. 56. As Reinisch and Weber point out, it is somewhat unfortunate that the European Court did not look at alternative legal remedies while looking at proportionality. See Reinisch \& Weber, 'In the Shadow of Waite and Kennedy', pp. 85-86.

74) Idem, paras. 57-67. In fact, the Court seemed so preoccupied with the effects - or lack thereof - of jus cogens that it forgot all about the proportionality test. Al-Adsani argued that the fact that the alleged violation was torture, and thus the violation of a jus cogens norm, would have a decisive effect on the proportionality test. The Court does not really address this argument. The same is true for the dissenting opinion of Rozakis et al. Only Judge Loucaides, in his Dissenting Opinion, looks at the influence of jus cogens on proportionality.

75) This question needs to be asked, because in para. 5.11 of 'Judgment in the Incidental Proceedings', the Dutch Court already indicated that the two types of immunity are 'very dissimilar to each other', and that one may not transfer rights and obligations from the one to the other.

76) In fact, Al-Adsani refers to Waite and Kennedy in this respect. See para. 59, Waite and Kennedy. See also Reinisch \& Weber, 'In the Shadow of Waite and Kennedy', pp. 78-79; Reinisch, International Organizations before National Courts, p. 304. 
unilateral interference by individual governments'. ${ }^{77}$ When concluding that respecting the Agency's immunity was proportionate, the Court remarked that 'a material factor [in deciding proportionality] is whether the applicants had available to them reasonable alternative means to protect effectively their rights under the Convention' ${ }^{78}$

If we presume for the moment that the Netherlands does have human rights obligations with regard to the plaintiffs, ${ }^{79}$ and apply the Waite and Kennedy rationale to the current case, we need to find out whether ensuring the proper functioning of the UN free from the interference of local judges is a legitimate aim. We must also examine whether the acceptance of the absolute immunity of the UN before the Dutch Court is a proportionate means to secure that aim, despite the fact that it hinders the right to a fair trial in relation to something as dramatic as genocide, and despite the fact that there is no alternative dispute settlement mechanism available. ${ }^{80}$ If the proportionality threshold is not met, then the Dutch Court's acceptance of the immunity of the United Nations could constitute a violation, by the Netherlands, of the human right to a fair trial. ${ }^{81}$

However, the Dutch Court found two ways to avoid this clash. First, the Dutch Court suggested that the Netherlands might not have any obligations,

77) Waite and Kennedy, para. 63.

78) Waite and Kennedy, para. 68. See also Singer, 'Jurisdictional Immunity of International Organizations,' pp. 149-150, 163; Reinisch, 'The Immunity of International Organizations and the Jurisdiction of their Administrative Tribunals', Chinese Journal of International Law, vol. 7, no. 2, 2008, p. 292.

79) According to Article 1 of the European Convention, the Netherlands only has the duty to secure to everyone within its jurisdiction the rights and freedoms defined in the Convention, and thus not to all the world citizens. The last sentence of para. 5.24 of the Dutch Court's judgment suggests, rightly so, that the Netherlands may not have obligations under the European Convention to the Mothers.

80) On this balance, see also Cameron, 'Human Rights Accountability of International Civil Administrations to the People Subject to Administration', in Human Rights \& International Legal Discourse, Vol. 1, no. 2, 2007, pp. 290-296; paras. 288-289, Kadi (CFI); Wellens, 'Accountability of International Organizations: Some Salient Features', in American Society of International Law Proceedings, vol. 97, 2003, pp. 244-245; Gerster, Rotenberg, 'Article 105', p. 1318; Reinisch \& Weber, 'In the Shadow of Waite and Kennedy', p. 68.

81) See also Wellens, 'Fragmentation of International Law and Establishing an Accountability Regime for International Organizations: The Role of the Judiciary in Closing the Gap', in Michigan Journal of International Law, vol. 25, 2004, p. 1177; Reinisch, International Organizations before National Courts, pp. 288-289; Singer, 'Jurisdictional Immunity of International Organizations', p. 58. 
under the European Convention on Human Rights, with regard to the Mothers of Srebrenica. ${ }^{82}$ Since this issue will only be addressed by the Court in the principal judgment, it cannot be assessed at length here. ${ }^{83}$ Second, the Dutch Court essentially believed that the European Convention could never be an impediment to the UN's efforts to maintain international peace and security. ${ }^{84}$ This argument was based on Behrami. In Behrami, the European Court said that it lacked the competence to decide upon acts committed under a UN Security Council Chapter VII mandate, regardless of under whose authority the acts were effectively carried out. ${ }^{85}$ The European Court failed to fully explain its conclusion, only stating that to apply the Convention 'would be to interfere with the fulfillment of the UN's key mission in this field including [...] with the effective conduct of its operations' ${ }^{86}$ It may be that the European Court was implicitly relying on Article 103 of the UN Charter, which supposedly gives priority to obligations arising under the UN Charter. ${ }^{87}$ As mentioned above, the Dutch Court was not that impressed by this Article, referring to the equally 'peremptory' character of jus cogens obligations and human rights norms. ${ }^{88}$ Nonetheless, the Dutch Court followed Behrami, and concluded that because the acts (and omissions) were carried out in the context of a UN peacekeeping mission, the plaintiffs could not rely on the

82) See last sentences of para. 5.24, Judgment in the Incidental Proceedings. See also paras. 4.14.2 of Mustafic, and 4.12.3 of Nuhanovic. Those that do are usually the State where the organization has its seat (USA) or the State where the asserted wrongful act was committed (Bosnia). It is difficult to invoke article 6 of the European Convention against these States: Bosnia only became a party in 2002, and the USA is obviously not a party and it never will.

83) The Court does refer to it in the last sentence of para. 5.24, Judgment in the Incidental Proceedings.

84) See paras. 5.22 and 5.24, Judgment in the Incidental Proceedings. See also Singer, 'Jurisdictional Immunity of International Organizations', pp. 84-88, 163; and see Wellens, Remedies against International Organizations, p. 214; International Law Association, 'Berlin Conference (2004)', p. 228.

85) See paras. 146-152, Grand Chamber of the European Court of Human Rights, Decision as to the Admissibility of Application no. 71412/01 by Agim Behrami and Bekir Behrami against France and Application no. 78166/01 by Ruzhdi Saramati against France, Germany and Norway, Decision of 2 May 2007 ('Behrami').

86) Para. 149, Behrami.

87) One would expect the European Court to rely on Article 103 UN Charter to justify this hierarchy. The Article is indeed referred to in paras. 26-27 (an introduction), and in the summary of the submissions of the parties: paras. 80, 97, 102, 106 and 113). In para. 147, the Court only refers to the Article, without explaining its significance.

88) See para. 5.16, Judgment in the Incidental Proceedings. 
European Convention. ${ }^{89}$ Since there was no need for a balancing of interests, the Dutch Court did not need to look at the availability of alternative legal remedies at UN-level, which according to Waite and Kennedy, would have been a 'material factor' in that balance. ${ }^{90}$

Thus the conclusion was that ' $\mathrm{t}$ ] he Court's inquiry into a possible conflict between the absolute immunity valid in international law of the UN and other standards of international law does not lead to an exception to this immunity' ${ }^{91}$

\section{Concluding Comments and a Look into the Future}

With the failure of the plaintiffs' case, the Dutch Court had no choice but to declare that it had no jurisdiction over the action taken against the United Nations. ${ }^{92}$ Although the outcome may not have been satisfactory for all, it should be noted that the UN did apologize for what went wrong in Srebrenica and elsewhere. ${ }^{93}$ In addition, the UN's immunity before domestic courts and

89) Idem, para. 5.22. In para. 5.24, the Dutch Court also referred to some factual differences between the UN and the European Space Agency, without convincingly explaining their legal significance: the UN has global membership whilst the European Space Agency has European membership. It is also true that the United Nations was established before the European Convention and the Space Agency thereafter, although the practice of peacekeeping does not predate the European Convention. The first peacekeeping force was the United Nations Emergency Force (UNEF). It was established, by the General Assembly (!), in 1956. See A/RES/1000 (ES-I), of 5 November 1956. See den Dekker, Immunity of the United Nations before the Dutch Courts, pp. 7-8. Finally, it is worth mentioning here that the European Court of Justice recently stated that European legislation implementing a resolution of the Security Council adopted under Chapter VII of the UN Charter could sometimes be annulled by the Court if the legislation failed to respect certain fundamental human rights (paras. 280-328, and 333-353, Kadi (ECJ)). However, the European Court believed this situation ought to be distinguished from the judicial review of acts implementing a Security Council resolution, if those acts were directly attributable to the United Nations, as was the case in Behrami (paras. 310-314, Kadi (ECJ)).

90) Idem, paras. 5.23-24. If it did, it would also need to look at the quality of that alternative, i.e. whether this alternative meets the basic conditions for a fair trial. See Reinisch, International Organizations before National Courts, pp. 306-312.

91) Idem, para. 5.26. A similar claim, based on the fair trial article of the International Covenant on Civil and Political Rights (ICCPR), only got one sentence: '[t]esting against article 14 ICCPR does not lead to a different outcome' (para. 5.26, Judgment in the Incidental Proceedings.) Since the Court did not give much attention to it, we will also not discuss Article 14 ICCPR.

92) Idem, Section 6.

93) See Wellens, Remedies against International Organizations, pp. 193-197. 
the lack of alternative dispute settlement mechanisms does not mean that the $\mathrm{UN}$ is not liable at all for its failures. ${ }^{94}$ It could be argued, however, that such liability is meaningless if the UN can never be held accountable. One positive outcome of this case could have been - or be - the establishment, by the UN, of an impartial tribunal to deal with claims relating to the Srebrenica genocide.

We may now look at what is to be expected in the future. The law firm representing the Mothers of Srebrenica has already indicated it will appeal the judgment, taking the case to the European Court of Human Rights if necessary. ${ }^{95}$ It is clear why the Mothers of Srebrenica prefer to have the UN onboard. When the United Nations is excluded from the case, it will be more tempting for the Netherlands to argue that the failures in Srebrenica should be attributed to the United Nations, and not to the Netherlands. ${ }^{96}$

In fact, this issue of attribution has already been dealt with by the very same District Court in The Hague. In two cases not formally related to the immunity decision which is the focus of this article, the Dutch District Court concluded that the acts of the Dutch peacekeepers in Srebrenica should be attributed to the United Nations, and not to the Netherlands. ${ }^{97}$ The Dutch Court, ${ }^{98}$ the European Court of Human Rights, ${ }^{99}$ the International Law Commission (ILC), ${ }^{100}$ the United Nations and most of its member states ${ }^{101}$ all

94) Blokker \& Schermers, International Institutional Law, p. 1005.

95) In a Press release July 10, 2008: Mothers of Srebrenica Shall Appeal and Deny Absolute Immunity of the $U N$, the law firm of the Mothers remarked that they will appeal the decision.

96) Indeed, the Mothers already noted that, now that the UN's immunity has been accepted, 'the State of The Netherlands in the main action will argue that it is not the State of The Netherlands that is responsible, but rather that it is the UN that is responsible for the events prior to, during and after the fall of Srebrenica.' Statement of Defence in the Interim Proceedings, para. 6.

97) See paras. 4.8-4.17 of Mustafic, and 4.7-4.15 of Nuhanovic, already referred to above.

98) See paras. 4.10-4.13 of Mustafic, and 4.8-4.11 of Nuhanovic.

99) According to the European Court, UNMIK was a subsidiary organ of the UN, like peacekeeping forces, and, also like peacekeeping forces, it was established by the Security Council and 'fully answerable' to it. And thus, according to the European Court, its acts were attributable to the UN (paras. 142-143, Behrami). The same acts could not be attributed to the respondent States (paras. 151-152).

100) See Article 5 of the Draft Articles on Responsibility of International Organizations provisionally adopted so far by the ILC, in para. 343, ILC, Report on the Work of its Fifty-Ninth Session, August 2007, UN Doc. A/62/10; and pp. 110-115, ILC, Report on the Work of its Fifty-Sixth Session, August 2004, UN Doc. A/59/10.

101) The Member States of the UN, when asked about 'the extent to which the conduct of peacekeeping forces is attributable to the contributing State and the extent to which it is attributable 
agreed that, in general, the acts of peacekeeping forces should be attributed to the UN. The opinions varied when it came to exceptions to this general rule. ${ }^{102}$ According to the UN and the ILC, the question of attribution and responsibility ultimately depends on who has 'effective control'; ;03 the European Court believed it depends on 'ultimate and overall control'; ${ }^{104}$ and the Dutch Court

to the United Nations' (see Report of the International Law Commission (Fifty-Fifth Session), August 2003, UNDoc. A/58/10, para. 27), gave varying replies. A majority, however, seemed to believe that the actions of peacekeepers should be attributed first and foremost to the Organization. See para. 44, Second Report on Responsibility of International Organizations. The UN's reply can be found at p. 17, Responsibility of International Organizations: Comments and Observations Received from International Organizations, 25 June 2004, UNDoc. A/CN.4/545. See also para. 36, Second Report on Responsibility of International Organizations.

102) See also Condorelli, 'Le Statut des Forces de l'ONU et le Droit International Humanitaire', in Rivista di Diritto Internazionale, vol. 78, no. 4, 1995, esp. p. 897; Saura, 'Lawful Peacekeeping: Applicability of International Humanitarian Law to United Nations Peacekeeping Operations', Hastings Law Journal, vol. 58, no. 3, 2007, pp. 527-528; Sari, 'Jurisdiction and International Responsibility in Peace Support Operations: The Behrami and Saramati Cases', Human Rights Law Review, vol. 8, no. 1, 2008, p. 159; International Law Association, 'Berlin Conference (2004)', pp. 190-191, 195-196, and 200-204; Section 3.3, 4.3, 5.2.2, Advies inzake Aansprakelijkheid voor Onrechtmatige Daden tijdens UN Vredesoperaties; para. 7, Gaja, Second Report on Responsibility of International Organizations, 2 April 2004, UNDoc. A/CN.4/541 (a big part of the report is devoted explicitly to peacekeeping: see paras. 34-44). See also p. 517 of Larsen, 'Attribution of Conduct in Peace Operations: The 'Ultimate Authority and Control' Test,' European Journal of International Law, vol. 19, 2008.

103) For the UN, see Financing of the United Nations Protection Force, 20 September 1996, UNDoc. A/51/389, paras. 17-18. See also section 3.3, Advies inzake Aansprakelijkheid voor Onrechtmatige Daden tijdens UN Vredesoperaties; Zwanenburg, 'De Lords, het EVRM en het Handvest: de Zaak Al-Jedda', in Militair-rechtelijk Tijdschrift, vol. 101, no. 5, 2008, pp. 138-140; Sari, 'Jurisdiction and International Responsibility in Peace Support Operations', pp. 164-165; para. 40, Second Report on Responsibility of International Organizations; Starmer, 'Responsibility for Troops Abroad: UN Mandated Forces and Issues of Human Rights Accountability', in European Human Rights Law Review, Vol. 2008, No. 3, p. 322. For the ILC, see Article 5 of the Draft Articles on Responsibility of International Organizations, and the commentary already referred to above; para. 41, Second Report on Responsibility of International Organizations. See also Larsen, 'Attribution of Conduct in Peace Operations', p. 516.

104) See paras. 133-141 (for KFOR) and 142 (for UNMIK), Behrami. See also Starmer, 'Responsibility for Troops Abroad', pp. 325-326; Watson, 'Behrami v. France: Constructive Blue Helmets Protect KFOR Nations from Accountability', Tulane Journal of International \& Comparative Law, vol. 16, 2008, p. 589. On the inconsistency between the European Court and the UN, see also Bodeau-Livinec, Buzzini \& Villalpando, Behrami \& Behrami v. France, p. 326. 
believed that only if 'the State cut across the United Nations command structure' would there be 'scope for attribution to the State'. ${ }^{105}$

This was clearly not the case in Srebrenica; ${ }^{106}$ and thus, in view of the Dutch District Court, the Netherlands could not be held responsible for any breach of contract or wrongful act committed by Dutchbat. ${ }^{107}$

105) The Court refers to the possibility that Dutchbat was ordered by the Dutch State to ignore UN orders, or shown themselves under the command of the Netherlands. See paras. 4.16.1 of Mustafic, and 4.14.1 of Nuhanovic. In para. 4.15 of Mustafic and 4.13 of Nubanovic, the Court suggested that the UN and troop-contributing nations may agree to hold the troop-contributing state responsible in exceptional circumstances, but there was no such agreement in this case. 106) See paras. 4.16.1-4.16.5 of Mustafic, and 4.14.1-4.14.5 of Nubanovic. See also Siekmann, 'The Fall of Srebrenica and the Attitude of Dutchbat from an International Legal Perspective', the Yearbook of International Humanitarian Law, vol. 1, 1998, p. 303.

107) See paras. 4.5, 4.7 and 4.17 of Mustafic, and 4.3, 4.5 and 4.15 of Nuhanovic. 